\title{
РАСПРОСТРАНЕНИЕ ИНФЕКЦИОННЫХ ЗАБОЛЕВАНИЙ ПТИЦ БАКТЕРИАЛЬНОЙ ЭТИОЛОГИИ В ВЕРХНЕМ ПРИАМУРЬЕ
}

\author{
Z.A. Litvinova, N.M. Mandro, P.V. Punina
}

\section{THE SPREADING OF BACTERIAL INFECTIOUS DISEASES OF THE POULTRY IN THE UPPER AMUR REGION}

Литвинова Зоя Александровна - канд. ветеринар. наук, доц., зав. каф. ветеринарносанитарной экспертизы, эпизоотологии и микробиологии Дальневосточного государственного аграрного университета, г. Благовещенск.

E-mail: litvinova-08@mail.ru

Мандро Николай Михайлович - д-р ветеринар. наук, профр. каф. ветеринарно-санитарной экспертизы, эпизоотологии и микробиологии Дальневосточного государственного аграрного университета, г. Благовещенск. E-mail: mnm0351@mail.ru

Пунина Полина Викторовна - асп. каф. ветеринарно-санитарной экспертизы, эпизоотологии и микробиологии Дальневосточного государственного аграрного университета, г. Благовещенск. E-mail: evsova@gmail.com

Изучены вопросы распространения бактериальных болезней сельскохозяйственных птии на территории Верхнего Приамурья в период с 2011 по 2017 г. В работе использовали материалы ветеринарной отчетности $\mathrm{C}$ применением методики С.И. Джупины, В.А. Ведерникова (1981). Цифрровой материал обрабатывали с использованием программы для работы с электронными таблицами «Microsoft Excel». На meppuтории Верхнего Приамурья за изученный период было зарегистрировано семь нозологических единии инфрекционных заболеваний сельскохозяйственных птии бактериальной этиологии: колибактериоз, орнитоз, сальмонеллез, стафрилококкоз, туберкулез, пастереллез и протейная инфекция. Наиболее высокие показатели значимости в эпизоотическом процессе установлены у таких заболеваний птицы, как колибактериоз (56,23\%), стафилококкоз (24,58 \%) и сальмонеллез (13,61\%), наименьшие показатели выявлены у туберкулеза (2,79 \%), протейной ин-
Litvinova Zoya Alexandrovna - Cand. Veterinary Sci., Assoc. Prof., Head, Chair of Veterinary and Sanitary Examination, Epizootology and Microbiology, Far Eastern State Agrarian University, Blagoveshchensk.

E-mail: litvinova-08@mail.ru

Mandro Nikolay Mikhaylovich - Dr. Veterinary Sci., Prof., Chair of Veterinary and Sanitary Examination, Epizootology and Microbiology, Far Eastern State Agrarian University, Blagoveshchensk.

E-mail:mnm0351@mail.ru

Punina Polina Victorovna - Post-Graduate Student, Chair of Veterinary and Sanitary Examination, Epizootology and Microbiology, Far Eastern State Agrarian University, Blagoveshchensk.

E-mail: evsova@gmail.com

фрекции (1,56 \%), пастереллеза (0,97 \%) и орнитоза (0,26 \%). Наибольшие изменения проиентного соотношения среди бактериальных болезней на территории Верхнего Приамурья отмечены в 2013-2014 ге. При идентификации бактерий из представленного патологического материала за все изученные годы выделяли Salmonella enteritidis, Salmonella gallinarum (Salmonella pullorum), Salmonella newport, Salmonella gege, Micobacterium avium, Proteus mirabilitis, Staphylococcus aureus, Pasteurella multocida, Chlamydia psittaci, также выделено 23 серотиna Echerichia coli, наиболее часто диагностируемыми из которых явились 078, 018, 035, 02, 041. Распространение бактериозов среди сельскохозяйственных птиц характеризовалось разной степенью стабильности. Неблагополучные районы по бактериальным болезням птиц за период 2011-2017 г2. приурочены $\kappa$ южной природно-хозяйственной зоне Амурской области, являющейся приграничной терpuторией. 
Ключевые слова: эпизоотическая ситуация, бактериальные инфрекции птии, сельскохозяйственная птица, Верхнее Приамурье.

The problems of spreading bacterial diseases of the poultry in the Upper Amur Region in the period from 2011 to 2017 were studied. In the research the data of veterinary reporting materials using the method of S.I. Dzhupina, V.A. Vedernikov (1981) were used. Digital information was processed using the program for working with spreadsheets "Microsoft Excel". In the Upper Amur Region for the period studied 7 nosological units of infectious diseases of the poultry of bacterial etiology were recorded: colibacteriosis, ornithosis, salmonellosis, staphylococcosis, tuberculosis, pasteurellosis and proteus infection. The highest indicators of significance in epizootic process were found in the diseases of the poultry such as colibacteriosis (56.23\%), staphylococcosis (24.58 \%) and salmonellosis (13.61\%), the lowest indicators for tuberculosis (2.79\%), proteus (1.56\%), pasteurellosis (0.97\%) and ornithosis (0.26\%). The largest changes in the percentage of bacterial diseases in the Upper Amur Region were noted in 2013-2014. While bacteria identification among given pathological material Salmonella enteritidis, Salmonella gallinarum (Salmonella pullorum), Salmonella newport, Salmonella gege, Micobacterium avium, Proteus mirabilitis, Staphulococcus aureus, Pasteurella multocida, Chlamydia psittaci, 23 serotypes of Echerichia coli were also isolated, the most frequently encountered of which were 078, 018, 035, 02, 041. The spread of bacteriosis among the poultry was characterized by varying degrees of stability. Dysfunctional areas for bacterial diseases of the poultry for the period 2011-2017 confined to the southern part of the Amur Region being boundary territory.

Keywords: epizootic situation, poultry bacterial infections, poultry, Upper Amur Region.

Введение. Развитие птицеводческой отрасли является одной из приоритетных задач в сфере сельскохозяйственной промышленности не только в Российской Федерации, но и в общемировом пространстве. Птицеводство относится к наиболее экономически выгодным и рентабельным моделям производства, что сти- мулирует высокий интерес к нему на протяжении уже длительного периода времени [1]. Важным звеном сохранения положительной динамики экономических показателей является поддержание благополучной эпизоотической ситуации на территории подконтрольных регионов, особенно граничащих со странами с нестабильной ситуацией по заразным заболеваниям сельскохозяйственных животных и птицы [2].

Среди инфекционных заболеваний птицы значительный процент составляют болезни бактериальной этиологии. Как правило, они возникают при несоблюдении технологии содержания и кормления, а также нарушениях зоогигиенических норм, приводящих к контактам с синантропной птицей [3-5].

Активный мониторинг за распространением инфекционных болезней птиц необходим для эффективного реагирования и предупреждения потерь среди поголовья, а также для своевременной разработки и внедрения эффективных противоэпизоотических мероприятий [2, 6]. Ведущее место в борьбе с бактериальными болезнями птицы также занимает своевременная специфическая профилактика - вакцинация [7].

Цель работы. Изучение распространения бактериальных болезней сельскохозяйственных птиц в Верхнем Приамурье в период с 2011 по 2017 год путем анализа материалов ветеринарной отчетности.

Материалы и методы исследования. Распространение инфрекционных заболеваний сельскохозяйственной птицы изучали путем анализа материалов ветеринарной отчетности за период 2011-2017 гг. В работе использовали методики С.И. Джупины, В.А. Ведерникова (1981) [8]. Цифрровой материал обрабатывали С использованием программы «Microsoft Excel».

Результаты исследования и их обсуждение. В результате исследования установлено, что в Верхнем Приамурье за период 2011-2017 гг. было зарегистрировано семь нозологических единиц инфекционных заболеваний сельскохозяйственных птиц бактериальной этиологии: колибактериоз (56,23 \%), стафилококкоз (24,58 \%), сальмонеллез (13,61 \%), туберкулез (2,79\%), протейная инфекция $(1,56 \%)$, пастереллез $(0,97 \%)$, а также орнитоз $(0,26 \%)$ (рис.). 


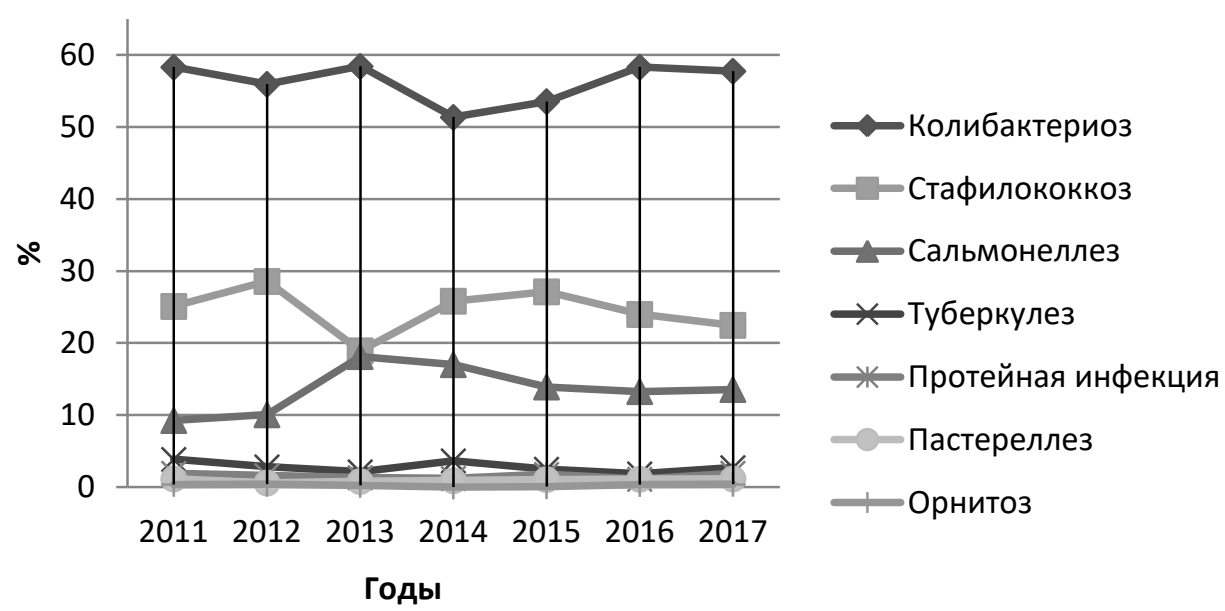

Удельный вес инфекционных болезней птиц бактериальной этиологии на территории Верхнего Приамурья за период с 2011 по 2017 г., \%

Колибактериоз является наиболее распространенным заболеванием птиц бактериальной этиологии в Верхнем Приамурье. В 2011 г. удельный вес по колибактериозу составил 58,30 \% с последующим снижением значимости в 2014 г. $(51,35 \%)$. В 2015 г. удельный вес колибактериоза составил 53,54 \% с увеличением к 2017 г. до $57,75 \%$. За исследуемый период из 19147 проб исследованного биологического материала установлено 2705 (13,49 \%) положительных по возбудителю колибактериоза. Чаще всего E.coli выделяли от цыплят в возрасте 1-10 дней $(82,13 \%)$, реже у птиц старшего возраста. Неблагополучными по данному заболеванию были Благовещенский, Бурейский, Ивановский, Михайловский, Ромненский, Свободненский, Тамбовский районы Приамурья. При серологической диагностике было выделено 23 серотипа E.coli. Наиболее часто диагностируемыми были серологические типы 078 (78,67 \%), 018 (61,24\%), O35 (29,81\%), O2 (28,01\%), O41 (27,17\%).

За период с 2011 по 2017 год возбудителя стафилококкоза выделяли из патологического материала сельскохозяйственных птиц личных подсобных и птицеводческих хозяйств Благовещенского, Белогорского, Бурейского, Ивановского, Ромненского, Свободненского районов. В 2012 г. показатель удельного веса стафилококкоза в структуре других бактериальных заболеваний птиц был максимальный и составил $28,57 \%$. В целом значение показателя с 2011 по 2017 г. снизилось с 25,10 до 22,48 \%. При бактериологическом исследовании патоло- гического материала выявляли возбудителя Staphylococcus aureus.

За период с 2011 по 2017 г. при бактериологическом исследовании патологического материала и фекалий от птиц выявляли возбудителя сальмонеллеза. Удельный вес сальмонеллеза в структуре бактериозов птиц в среднем составил $13,61 \%$. Наибольшее значение показателя установлено в 2013 г. (18,13 \%) с последующим снижением к 2017 г. (13,28 \%). Сальмонеллез птиц выявляли в Благовещенском, Белогорском, Ивановском, Тамбовском, Свободненском и Серышевском районах Амурской области. Типовой состав сальмонелл, изолированных от сельскохозяйственной птицы за 2011-2017 гг., был представлен S.enteritidis (72,10 \%), S.gallinarum (pullorum) $(23,57 \%)$, S.newport (3,83\%), S.gege $(0,50 \%)$. В возрастном аспекте сальмонелл $60,05 \%$ выделяли чаще от павших цыплят в возрасте до 3 недель; 23,11 \% приходилось на цыплят 20-дневного возраста, 16,84 \% - на молодняк до 3 месяцев.

Наименьший удельный вес среди выявленных заболеваний сельскохозяйственной птицы имели туберкулез, протейная инфекция, пастереллез и орнитоз. В указанный период показатели удельного веса каждого из заболеваний не достигали 3,0 \%, за исключением туберкулеза. В 2011 г. удельный вес туберкулеза в структуре заболеваемости птицы составил 3,86 \%, в 2014 г. - 3,65 \%. Неблагополучными районами по данным инфекционным заболеваниям являлись Благовещенский, Ивановский, Константинов- 
ский, Магдагачинский, Михайловский, Тамбовский, Тындинский, Сковородинский. При бактериологическом исследовании выделяли Micobacterium avium, Proteus mirabilitis, Pasteurella multocida, Chlamydia psittaci.

Заключение. Таким образом, на территории Верхнего Приамурья среди сельскохозяйственной птицы регистрируют семь нозологических единиц инфекционных заболеваний бактериальной этиологии. Наиболее высокие показатели значимости в эпизоотическом процессе среди данных заболеваний установлены у колибактериоза $(56,23 \%)$, стафилококкоза $(24,58 \%)$ и сальмонеллеза $(13,61 \%)$, наименьшие показатели выявлены у туберкулеза (2,79\%), протейной инфекции $(1,56 \%)$, пастереллеза $(0,97 \%)$ и орнитоза $(0,26 \%)$. При идентифрикации бактерий выделяли Echerichia coli, Salmonella enteritidis, Salmonella gallinarum-pullorum, Salmonella newport, Salmonella gege, Proteus mirabilitis, Micobacterium avium Staphylococcus aureus, Chlamydia psittaci, Pasteurella multocida. Распространение бактериозов среди сельскохозяйственных птиц характеризовалось разной степенью стабильности. Неблагополучные районы по бактериальным болезням птиц приурочены к южной природно-хозяйственной зоне Амурской области. Для снижения заболеваемости сельскохозяйственной птицы бактериальными инфекциями необходимо соблюдать ветеринарносанитарные и гигиенические правила содержания, кормления и разведения, а также проводить своевременную вакцинацию поголовья и иммуномодулирующую терапию.

\section{Литература}

1. Зуева О.Н., Беляев Н.М., Донскова Л.А. Управление отраслью птицеводства в условиях логистической интеграции: мировые и российские тренды развития, реалии, проблемы и перспективы // Вестник Удмуртского университета. 2017. № 6. С. 22-30.

2. Литвинова З.А., Мандро Н.М. Цикличность и периодичность проявления эпизоотического процесса при сальмонеллезе сельскохозяйственных животных в Приамурье // Вестник АГАУ. 2019. № 5 (175). С. 109-114.

3. Асмолова О.Л., Землянская Н.И. Микрофлора кормов, воды, инвентаря и оборудо- вания на птицеводческих фабриках // Вестник КрасГАУ. 2015. № 5. С. 154-156.

4. Эпизоотологический мониторинг инфекционных болезней птиц в Республике Крым / Н.Г. Воротилова, С.И. Данильченко, И.Б. Ионкина [и др.] // Известия сельскохозяйственной науки Тавриды. 2015. №3 (166). C. 81-90.

5. Микробиологические риски в промышленном птицеводстве и животноводстве / В.И. Фисинин, В.И. Трухачев, И.П. Салеева [и др.] // Сельхозбиология. 2018. № 6. C. $1120-1130$.

6. Распространение инфекционных болезни птиц в Республике Таджикистан / Дж.М. Шоназар, Ш.А. Турдиев, З.Д. Курбонбекова [и др.] // Ученые записки КГАВМ им. Н.Э. Баумана. 2016. № 1. С. 86-90.

7. Новикова О.Б., Павлова М.А., Бартенев А.А. О проблеме колибактериоза в птицеводстве // Эфффективное животноводство. 2018. № 6 (145). C. 46-48.

8. Джупина С.И., Ведерников В.А. Изучение эпизоотической ситуации инфекционных болезней сельскохозяйственных животных в области (крае, АССР): метод. рекомендации / ВАСХНИЛ; Сиб. отд-ние; Ин-т эксперим. ветеринарии Сибири и Дальнего Востока. Новосибирск: СО ВАСХНИЛ, 1981. 16 с.

\section{Literatura}

1. Zueva O.N., Beljaev N.M., Donskova L.A. Upravlenie otrasl'ju pticevodstva $\mathrm{v}$ uslovijah logisticheskoj integracii: mirovye i rossijskie trendy razvitija, realii, problemy i perspektivy // Vestnik Udmurtskogo universiteta. 2017. № 6. S. 22-30.

2. Litvinova Z.A., Mandro N.M. Ciklichnost' i periodichnost' projavlenija jepizooticheskogo processa pri sal'monelleze sel'skohozjajstvennyh zhivotnyh v Priamur'e // Vestnik AGAU. 2019. № 5 (175). S. 109-114.

3. Asmolova O.L., Zemljanskaja N.I. Mikroflora kormov, vody, inventarja i oborudovanija na pticevodcheskih fabrikah // Vestnik KrasGAU. 2015. № 5. S. 154-156.

4. Jepizootologicheskij monitoring infekcionnyh boleznej ptic v Respublike Krym / N.G. Vorotilova, S.I. Danil'chenko, I.B. Ionkina [i dr.] 
// Izvestija sel'skohozjajstvennoj nauki Tavridy. 2015. №3 (166). S. 81-90.

5. Mikrobiologicheskie riski $\mathrm{v}$ promyshlennom pticevodstve i zhivotnovodstve / V.I. Fisinin, V.I. Truhachev, I.P. Saleeva [i dr.] /I Sel'hozbiologija. 2018. № 6. S. 1120-1130.

6. Rasprostranenie infekcionnyh bolezni ptic $v$ Respublike Tadzhikistan / Dzh.M. Shonazar, Sh.A. Turdiev, Z.D. Kurbonbekova [i dr.] /I Uchenye zapiski KGAVM im. N.Je. Baumana. 2016. № 1. S. 86-90.
7. Novikova O.B., Pavlova M.A., Bartenev A.A. 0 probleme kolibakterioza $\mathrm{v}$ pticevodstve /I Jeffektivnoe zhivotnovodstvo. 2018. № 6 (145). S. 46-48.

8. Dzhupina S.I., Vedernikov V.A. Izuchenie jepizooticheskoj situacii infekcionnyh boleznej sel'skohozjajstvennyh zhivotnyh $\mathrm{v}$ oblasti (krae, ASSR): metod. rekomendacii I VASHNIL; Sib. otd-nie; In-t jeksperim. veterinarii Sibiri i Dal'nego Vostoka. Novosibirsk: SO VASHNIL, 1981.16 s 